\title{
The Status Of Rural Women's Health And Cassava Output In Nigeria
}

Cynthia W. Angba, University of Calabar, Nigeria

Augustine O. Angba, University of Calabar, Nigeria

\begin{abstract}
This study was carried out to analyze the influence of the health status of women farmers on their level of cassava production. The specific objectives are to; identify the socio-economic characteristics of the rural women in the area, ascertain common health problems they encounter and their health management techniques and the influence of the rural women's health status on level of cassava production in the area. A multi-stage random sampling technique was employed to select 200 women farmers in Ikom Local Government Area in Nigeria. Data was collected and analyzed using descriptive and inferential statistics. The study revealed that, majority of the women were in the age range of $40-50$ years, $71 \%$ were married, $78 \%$ traded alongside farming, $66.5 \%$ had some form of formal education, their family sizes range between 6-10 people and with a mean family size of 6 . Annual income of the farmers range between \#10,000 - \#14,000. The predominant practice was mixed cropping. Body pains, fever, malaria, headache, were the common ailment. While painful menstruation (20.5\%) was the most common reproductive disease. Results from the regression analysis shows that the household size, educational level and income are significantly related to the health status of the rural women while age and marital status are not significantly related. Health centers, patent medicine stores, family planning, leprosy centers were readily available in the villages surveyed clinic. As health status of the women improved, productivity was therefore expected to increase. On this basis, the policy of free health facilities for women was advocated if women cassava productivity is to increase. A policy of free medical facilities including good food to the rural women will boost their health status and productivity.
\end{abstract}

Keywords: Health Status; Rural Women; Nigeria; Health Management

\section{INTRODUCTION}

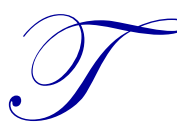

he development of agriculture has a direct impact on food consumption and health. In African countries, food production has not been able to meet the population increase. Furthermore of the 45 developing countries with low levels of food security since 1991, 31 were in sub-Saharan Africa. Almost three-quarter of the world's population lives in agricultural societies geared towards survival relying on local raw materials and powered by man and animals (Oriole, 2009).

According to report by food and agricultural organization (FAO) 2002, women in many sub-Saharan countries provides above $70 \%$ of the agricultural labour to produce food crop for household consumption and for sales, $90 \%$ of the hoeing and weeding work and $60 \%$ of the harvesting and marketing activities.

Although Nigeria has achieved remarkable development in mass education and civic consciousness, traditional agriculture is prominent and a situation where women are not always considered, development plants and other social inequalities cause detrimental effect to the health of the rural women whose main occupation is agriculture. Studies have shown that the fundamental requirement for attaining health are availability of adequate nourishment, shelter, access to location, productive employment, control over resources, positive inter-personal relations, availability and accessibility of health care services (IFPRI 2006) 
Why other health problems faced by women, reproductive health is another constraint that affects rural women and agricultural productivity Theresa (2004) mentioned that; productive health problems of leucorrhea, irregular bleeding and uterine turmoil, among the women was small. However, the proportion of abortion, still birth and pre-mature delivery was relatively high. Thus, it is found that even today women depend on abortion for controlling their fertility.

However, Ikom agricultural zone is a typical rural area and agriculture are the main occupation of the women coupled with the fact that women contribute $50 \%$ of the world's population that resides in rural areas of under developed countries were they perform their increasing indispensable roles in agriculture. A study of their health status and agricultural production of cassava output has become necessary.

Women, are major participants in agricultural production and taking into consideration the need to achieve food sufficiency, if the health status of women are not checked, it can become a set back to their productivity. Studies have shown that majority of women in developing countries lives in rural areas where traditional agricultural is prominent and social conditions dictate that they should marry young and have large families. These conditions coupled with limited opportunities for education and lacks of access to health services are harmful to women's health. .

Apart from diseases associated with their work, women have some peculiar problems that are associated with their sex and some cultural activities that have negative effect on their health. Due to these problems and many others, there is a need for research into the influence of the health status of women on agricultural output. Consequently, the study addressed the following objectives;

(1) Identify the socio-economic characteristics of rural women in the study area

(2) Ascertain common health problems that are encountered by the rural women and how these health related problem are managed

(3) Ascertain the influence of their rural women's health status on the levels of cassava production

\section{STATEMENT OF HYPOTHESIS}

The research hypothesis is thus stated in the null form:

Ho: there is no significant influence of the rural women's health status on their cassava output in Ikom agricultural zone.

\section{METHODOLOGY}

\section{Description of Study Area}

Cross River State is basically an agricultural state. About $75 \%$ of its people engage in subsistence agriculture. Despite the fact that the state is in the oil producing area of the Niger Delta, income levels are exceedingly low and poverty is endemic with over $70 \%$ of the population living below the international poverty line of US\$1 a day.

\section{Population, Sampling and Sampling Procedure}

The population of this study consists of all female cassava farmers in the study area. However, using appropriate technique, a representative sample was drawn for data collection. A multi stage random sampling technique was used to select 200 women cassava farmers from the four randomly selected cells from two blocks in the L.G.A. In the first stage, Ikom Agriculture zone was purposively chosen out of the three agriculture zones in the state. In the second stage, a random sample of two blocks (Ikom and Etung) was chosen out of the six blocks comprising the zone. In each of the blocks, two cells were chosen (Agbokim and Etomi in Etung and Ikom Urban 1 and Akparabong in Ikom). A random sample of 50 women per cell who cultivated cassava were chosen making up a total of 200 women cassava farmers used for the study. Structured questionnaire was used to elicit information from the respondents. Descriptive and inferential statistics was used to analyze the data collected. 
Table 1. Summary of Research Sample

\begin{tabular}{lccc}
\hline No of L.G.A. & No of Blocks Selected & No of Cells & No of Respondents \\
Ikom & 1 & 2 & 100 \\
Etung & 1 & 2 & 100 \\
Total & 2 & 4 & 200 \\
\hline
\end{tabular}

Source: Field survey 2012

\section{Instrumentation}

The instrument for the study was the structured questionnaire which was designed to obtain data using a four point Likert scale which ranged from Very Often, Often, Rarely and Not at all. Scoring was done as follows; $\mathrm{VO}=4, \mathrm{O}=3, \mathrm{R}=2$, and $\mathrm{NA}=1$. Reverse scoring was done for negative questions. The mean scores of each of the farmer's responses were estimated and used as the dependent variable. On the other hand, output of cassava was measured in $50 \mathrm{~kg}$ bags.

Data collected for this study were sorted, coded and computer analyzed. Descriptive statistics such as frequencies, percentages, tables and means were employed. One hypothesis was tested at the null form using multiple regression analyses.

A poll of these scores on each variable on the instrument was used to analyze responses. The instrument was subjected to face validity.

\section{RESULTS AND DISCUSSION}

The results of the study show that Majority of the respondents (43\%) fell within the age brackets of less than 30 years but not greater than 40 years. $41-50$ years $(30.5 \%)$ and above 50 years $26.5 \%$. This shows that majority of the farmers were of middle age.

Majority of the respondents $(35.5 \%)$ were married about $30.0 \%$ separated while $18.0 \%$ and $16.5 \%$ were single and widowed respectively. This shows that marriage has a great influence in farming activities. This is in line with an earlier study conducted by Ekong and Olowu (2002) that every woman in the rural setting is expected to marry so as to have access to farmland.

Educationally, $31.5 \%$ of the respondents had no formal education, $30 \%$ had secondary education while $20 \%$ and $16 \%$ had attained tertiary and primary education respectively. 
Table 2. Socio-Economic Characteristics of Respondents

\begin{tabular}{|c|c|c|c|}
\hline Variable & Categories & Frequency & Percent \\
\hline \multirow{3}{*}{ Age } & $30-40$ & 86 & 43.0 \\
\hline & $41-50$ & 61 & 30.5 \\
\hline & 51 and Above & 53 & 26.5 \\
\hline \multirow{4}{*}{ Marital Status } & Married & 71 & 35.5 \\
\hline & Widowed & 33 & 16.5 \\
\hline & Separated & 60 & 30.0 \\
\hline & Single & 36 & 18.0 \\
\hline \multirow{4}{*}{ Educational level } & Non-formal & 63 & 31.5 \\
\hline & Primary education & 32 & 16.5 \\
\hline & Secondary education & 60 & 30.0 \\
\hline & Tertiary education & 44 & 22.0 \\
\hline \multirow{3}{*}{ Secondary occupation } & Trading & 78 & 39.0 \\
\hline & Civil servants & 77 & 38.5 \\
\hline & Others & 45 & 22.5 \\
\hline \multirow{3}{*}{ Household size } & Less than 6 & 65 & 32.5 \\
\hline & $6-10$ & 79 & 39.5 \\
\hline & 11 and above & 56 & 27.8 \\
\hline \multirow{3}{*}{ Income (Per annum) } & Below N14,000 & 95 & 47.5 \\
\hline & $\mathrm{N} 15,000-24,000$ & 73 & 36.5 \\
\hline & $\mathrm{N} 25,000$ & 32 & 16.0 \\
\hline \multirow{4}{*}{ Income from cassava } & Below 5,000 & 48 & 25.0 \\
\hline & N6,000-9,000 & 53 & 26.0 \\
\hline & $\mathrm{N} 10,000-14,000$ & 69 & 34.0 \\
\hline & $\mathrm{N} 15,000-19,000$ & 30 & 15.0 \\
\hline \multirow{4}{*}{ Crop combination } & Cassava only & 47 & 23.5 \\
\hline & Cassava/maize/yams & 55 & 27.5 \\
\hline & Cassava/melon/cocoyam & 94 & 47.5 \\
\hline & Intercrop & 4 & 2.0 \\
\hline \multirow{3}{*}{ Cassava output in $50 \mathrm{~kg}$} & $1-3$ & 60 & 30.0 \\
\hline & $4-6$ & 106 & 53.0 \\
\hline & 7 and above & 34 & 17.0 \\
\hline
\end{tabular}

Source: Field Survey, 2012

This result shows that more than $60 \%$ of the respondents were able to read and write. The implication is that, the respondents would be able to interpret and comprehend information given to them in English, making it relatively easier for them to make decisions about adoption of modern technologies on their farms as well as influence decision on their health.

The study revealed that $39 \%$ of the respondents engaged in trade activities while $38.8 \%$ and $22.5 \%$ were civil servants and other activities respectively. This shows that, apart from cassava production, the respondents engaged themselves in other activities. This is in line with the IITA (1988) report which stated that, women in addition to farming, trade to generate extra income. The implication is that, income from the cassava production was not enough to sustain family income.

The household sizes of the respondents had family sizes ranging from 6-10 (37-5\%) less than 6(32.5\%) and above $10(21.5 \%)$. This shows that majority of the respondents had larger household sizes. This is in affirmation of FAO (1984) report that many rural women in the developing world consider large families to be essential in enabling them to cope with task as producers and major contributors to well being.

Majority of the respondents (47.5\%) earned below N14,000 per year while $36.5 \%$ and $16 \%$ earned between $\mathrm{N} 15,000-\mathrm{N} 24,000$ and N25,000 and above per year respectively. This low annual income confirms the finding of Ekong and Olowou (2002) that women in Nigeria work so hard but earn so little.

Furthermore income from cassava output from the study revealed that $34 \%$ of the respondents earned $\mathrm{N} 10,000-\mathrm{N} 14,000,26 \%$ earned N6,000 - N9,000 while 25\% earned below N5,000 and 15\% earned between 
N15,000- N19,000 and respectively. This confirms the fact that Nigerian women practice subsistence agriculture since their income from cassava is far below one dollar (N160) per day.

The cropping pattern of the respondents revealed that about $47.5 \%$ cultivated cassava, melon and cocoyam, $27.5 \%$ cultivated cassava, maize and yam while only $23.5 \%$ cultivated cassava only. This shows that the practice of mixed cropping helps to boost their income.

Most respondents (53\%) produce 4-6 bags of cassava per month, 30\% produce between 1-3 bags of cassava while only $17 \%$ produce more than 7 and above bags of cassava per month. This shows that women are looked upon by their family to provide food confirming FAO (2002) report that women accounted for 70-80\% of household food.

\section{Common Health Problems among the Respondents}

All of the respondents complained of regular body pain, $97 \%$ suffered from malaria, same with headache while $91 \%$ and $45 \%$ suffered from fever and other related health problems respectively as shown in Table 3 .

Table 3. Common Health Problems that Affect Respondents Farm Activities

\begin{tabular}{lcc}
\hline \multicolumn{1}{c}{ Illness } & Frequency & Percentage \\
\hline Body pain & 200 & 100 \\
Malaria & 194 & 97 \\
Fever & 182 & 91 \\
Headache & 194 & 97 \\
Others (Diarrhea rheumatism, hypertension, abdominal pain) & 90 & 45 \\
\hline
\end{tabular}

Source: Field survey, 2012

Majority of the respondents suffered from at least two of the above illnesses at a time. This finding is in line with IFPRI, (2006), that the higher incidences of skeletal muscular and postural health problems such as joint pains, back pains are perhaps indicative of their work-related health hazards.

Most of the respondents in terms of reproductive health related problems suffered from post delivery pains, $15.0 \%$ had abortion, $21.0 \%$ had still birth, $20.5 \%$ had painful menstruation, and $18.5 \%$ suffered post delivery pain while $9.5 \%$ had induced abortion as depicted in Table 4 below.

Table 4. Reproductive Health Problems of the Respondents

\begin{tabular}{lccr}
\hline \multicolumn{1}{c}{ Problems } & Frequency & Percentage & Mean \\
\hline Abortion & 30 & 15.0 & 10.24 \\
Induced abortion & 19 & 9.5 & 8.33 \\
Still birth & 42 & 21.0 & 9.44 \\
Painful menstruation & 41 & 20.5 & 12.10 \\
Post delivery pain & 37 & 18.5 & 11.06 \\
Tear during Delivery & 31 & 15.5 & 12.03 \\
\hline
\end{tabular}

Source: Field survey, 2012

According to the respondents, the reason for high incidence of abortions and still birth was due to excessive burden work, ignorance, lack of proper medical attention during fever, bleeding and abdominal pain. This is in conformity with reports by Theresa (2004) that reproductive health problems of leucorrhoea, irregular bleeding among others was small while problems such as abortion, still birth and premature delivery were relatively high.

\section{Health Management Techniques Adopted by the Respondents}

The result of the study as shown in Table 5 revealed that majority of the respondents patronized patent medicine dealers, $90 \%$ patronized health care centre while 13\% patronized cancer screening centres. Most of the respondent patronized more than one centres. They were satisfied with health care centres but the protocols involved hinder them from frequent visitation. These protocols consume time which the women felt they would have used in other activities which confirms the findings of Ekong and Olowu (2002) that sustaining women's participation in 
health-related projects is difficult largely because their primary concern is the welfare and nourishment of their children and their husband, they give high priority to income generating activities.

Table 5. Health Management Techniques Adopted by the Respondents

\begin{tabular}{lcc}
\hline \multicolumn{1}{c}{ Management Centre } & Frequency & Percentage \\
\hline Patent medicine dealers & 194 & 97 \\
Health centre & 180 & 90 \\
Cancer screening centre & 26 & 13 \\
\hline
\end{tabular}

Source: Field survey, 2012

Table 6 below presents the regression analysis values of the influence of rural women's health status on levels of cassava production in the studies area.

Table 6. The Regression Analysis Values of the Health Status of the Respondents on Cassava Output

\begin{tabular}{|c|c|c|}
\hline Variables & Functional Linear "A" & Double Logarithm \\
\hline Intercept & $\begin{array}{l}-482.56 \\
(763.601)\end{array}$ & $\begin{array}{l}-0.434 \\
(0.439)\end{array}$ \\
\hline Health status & $\begin{array}{l}1283.11 * * * \\
(223.796)\end{array}$ & $\begin{array}{l}0.109 * * * \\
(0.033)\end{array}$ \\
\hline Household size & $\begin{array}{l}148.189 \\
(911.229)\end{array}$ & $\begin{array}{l}0.131 * * * \\
(0.057\end{array}$ \\
\hline Age & $\begin{array}{c}28.912 \\
(17.562)\end{array}$ & $\begin{array}{c}0.111 \\
(0.083)\end{array}$ \\
\hline Marital status & $\begin{array}{l}-22.395 \\
(259.785)\end{array}$ & $\begin{array}{l}-0.012 \\
(0.026)\end{array}$ \\
\hline Education & $\begin{array}{l}0.0537 * * * \\
(25.978)\end{array}$ & $\begin{array}{l}0.040 * * * \\
(0.015)\end{array}$ \\
\hline Income & $\begin{array}{l}0.051^{* * *} \\
(0.005)\end{array}$ & $\begin{array}{l}0.787 * * * \\
(0.036)\end{array}$ \\
\hline $\mathrm{R}^{2}$ & 0.05 & 0.8 \\
\hline
\end{tabular}

f-ratio: $37.2805 ; * *$ significant at 5\%; *** significant at $1 \%$

The result of the regression analysis showed that the household size, education and income were significant while age and marital status were not significant. The result revealed that increase in household size is positively related to the health status of the respondents with $1 \%$ level of significance $(0.131)$. Large families enable the women to cope with tasks as producers and major contributors to well being. The result also showed that education and income are positively related to the health status of the respondents with a $1 \%$ level of significance of 0.053 and 0.040 respectively. This result coincides with that of Skimpi, (1987). This implies that increase in educational level has an important impact on improving the health status of the respondents. Also, a high level of income contributes a better health status of the respondents as indicated in the result. The result also revealed that age is positively related to the health status but not significant (28.912) while marital status is negatively related to the health status and not significant (-22.395).

\section{Test of Hypothesis}

There is no significant influence of rural women's health status on their cassava output in Ikom agricultural zone. The result of the test of hypothesis reveals that, all the coefficients except marital status had positive signs. However, only income, household size, and educational level were significant. The double log form was chosen as the lead equation. This shows that, the better the health status of the respondents, the higher their cassava production output. This agrees with Adisa, and Okunade (2005) that, a healthy adult with nutritionally adequate diets has a higher level of economic productivity in both owned farm production and labour market. Therefore, the null hypothesis is rejected and the alternate form is accepted. 


\section{SUMMARY, CONCLUSION, AND RECOMMENDATIONS}

The study discussed the prevalence of the common diseases among cassava farmers that affect their productivity in Ikom agricultural zone of Cross River State. It described the socio-economic characteristics of the rural women, the common health problems encountered and the health management techniques they adopt and the influence between these socio-economic characteristics with the women farmer's health. A total of 200 farmers were randomly selected from four farming communities in the zone that are involved in the study. Secondary data were collected using women's farmer's records while primary data were collected by means of questionnaires interview and guides. Statistical procedures include the use of percentages and frequencies. The finding shows that majority of the farmers (30.5\%) were 41-50 years indicating that majority of the farmers were of middle age. Most of them were married (35.5\%) while majority (66\%) had formal education.

However, $39.0 \%$ were traders, $38.8 \%$ and $22.5 \%$ were civil servants and others respectively. $39.5 \%$ had family size range of 6-10 with a mean household size of $6.53 .0 \%$ had $50 \mathrm{kgbags}$ of cassava output per month. Most of the respondent (34\%) made between N10,000 - N14,000. The common health problems among the respondents were body pain $(100 \%)$, malaria $(97 \%)$, fever $(91 \%)$, headache $97 \%$ and others $(45 \%)$ while reproductive health problems are painful menstruation, post delivery pain, still birth and induced abortion.

The coefficients of educational attainment, income and household size have significant and positive effects on cassava output while the coefficient of marital status have a significant and negative effect on cassava output. The coefficient of determination $\left(r^{2}=0.08\right)$ indicates $80 \%$ of the variation of cassava output in the area is explained by the independent variables.

The findings also revealed that the respondents mostly patronized patent medicine store in terms of health management but health centers were used when the problem persisted. The cassava output of the women can be improved when their health status is improved. Therefore, we recommend that, government should provide free health care and family planning services to the women and children to boost their agricultural productivity. There should also be an effective and integrated extension system that will produce a synergy between health and agriculture.

\section{AUTHOR INFORMATION}

Cynthia W. Angba, Dept. of Agricultural Economics and Extension, University of Calabar, Calabar - Cross River state, Nigeria. Corresponding author: cynthia.whiteley@yahoo.com

Augustine O. Angba, Dept. of Agricultural Economics and Extension, University of Calabar, Calabar - Cross River state, Nigeria. Email: drangba@yahoo.com

\section{REFERENCES}

Adisa, B. O. and Okunade, E. O. (2005). Women in agriculture and rural development in: Madukwe, M. S. (ed) Agricultural Extension in Nigeria. Agricultural Extension society of Nigeria (AESON) pg. 90.

Ekong, E. W. and Olowu, T. A. (2002). Women's access to agricultural production resources in Akwa Ibom State. Nigerian Journal of Rural sociology, 4(1), 60-62.

Food and agricultural organization of the United Nation (2002). Women, population and environment in agriculture and rural development policy challenges and responses. Rome: Food and agricultural organization.

International food policy research institutes (2006a). Understanding the links between agriculture and health focus is brief 7 of 16. Florida; University of Florida Press.

International institute of tropical agriculture, IITA (1998 research highlight for 1985, Ibadan: International Institute for tropical agriculture.

Oriole, E. O. (2009). A framework for food security and poverty reduction in Nigeria. European journal of social sciences. Vol. 8(1) pg 133.

Skimpi, D. K. (1987). Occupational health services and their integration to primary health care in Uganda. Proceedings of the regional ILO-Finnish symposium on occupational health and safety in East Africa, Marangil, Tanzania.

Theresa, E. O. (2004). Women workers in agriculture. Gender determination, working conditions and health status: Thiruvanan kerala Research programme on local level development. 
NOTES 